\title{
TAN MÁU CẤP DO CEFTRIAXONE: BIẾN CHỨNG NẬNG ĐE DQ̣A TÍNH MẠNG
}

\author{
Mai Thành Công ${ }^{1, 凶}$, Bùi Thị Tho², Nguyễn Thị Diệu Thúy ${ }^{1}$ \\ ${ }^{1}$ Trường Đại học Y Hà Nội \\ ${ }^{2}$ Bệnh viện Nhi Trung ương
}

Tan máu miễn dịch liên quan đến thuốc (DIIHA) là một biến chứng hiếm gặp và thường dễ bị bỏ sót chẩn đoán. Thực tế, đây lại là biến chứng nghiêm trọng, có thể gây suy tạng, thậm chí tử vong. Gần đây, ceftriaxone được ghi nhận là một trong những thuốc thường gặp nhất gây DIIHA. Chúng tôi báo cáo một trường hợp trẻ nam 19 tháng tuổi được chẩn đoán viêm phổi và điều trị bằng ceftriaxone tĩnh mạch 2 lần/ngày tại bệnh viện địa phương. Sau tiêm ceftriaxone 5 ngày, trẻ đột ngột xuất hiện tình trạng mạch nhanh, nhột và tiểu đỏ sẫm; được xử trí theo phác đồ sốc phản vệ và chuyển Bệnh viện Nhi Trung ương. Trẻ được chẩn đoán mắc tan máu miễn dịch liên quan đến ceftriaxone, ngừng sử dụng ceftriaxone và điều trị thành công bằng immunoglobulin tĩnh mạch. Tan máu miễn dịch liên quan đến ceftriaxone hiếm gặp nhưng có thể gây tổn thương đa cơ quan, đe dọa tính mạng. Các bác sĩ lâm sàng cần nhận biết biến chứng này để chẩn đoán sớm và chính xác, ngừng ngay thuốc tránh gây ra hậu quả nghiêm trọng cho bệnh nhân.

Từ khóa: Tan máu, tan máu miễn dịch liên quan đến thuốc, ceftriaxone, trẻ em.

\section{I. ĐẠT VẤN ĐÊ}

Tan máu miễn dịch liên quan đến thuốc (DIIHA: Drug induced immune hemolytic anemia) là một biến chứng hiếm gặp khi sử dụng thuốc, với tỉ lệ mắc mới ước tính khoảng 1/1000000 ca/năm. ${ }^{1}$ Tuy nhiên, trong thực tế tỉ lệ này có thể cao hơn do bị bỏ sót chẩn đoán.

Số loại thuốc được báo cáo gây ra DIIHA tăng lên trong những thập kỉ gần đây kể từ báo cáo đầu tiên vào đầu những năm 1950. Cho đến nay có hơn 130 loại thuốc được báo cáo gây ra DIIHA, ${ }^{2}$ phổ biến là kháng sinh, thuốc chống viêm và hoạt chất nhóm platinum. Trong số các kháng sinh gây ra DIIHA, nhóm cephalosporin thế hệ 2,3 và nhóm penicillin là hay gặp nhất. ${ }^{1,3}$

Tan máu do thuốc có thể do độc tính của thuốc gây phá hủy trực tiếp hồng cầu (như ribavirin) hoặc DIIHA do phản ứng miễn dịch

Tác giả liên hệ: Mai Thành Công

Trường Đại học Y Hà Nội

Email: Maithanhcong@hmu.edu.vn

Ngày nhận: 15/03/2021

Ngày được chấp nhận: 16/05/2021 liên quan đến thuốc gây ra tan máu. Các kháng thể liên quan đến DIIHA được phân thành hai nhóm chính: (1) kháng thể không phụ thuộc thuốc (drug-independent antibodies) là loại kháng thể có thể gắn với hồng cầu in vitro mà không cần sự có mặt của thuốc, đây là tự kháng thể trực tiếp với cấu trúc màng hồng cầu là chủ yếu, thuốc chỉ là một phần nhỏ không đáng kể trong vị trí gắn; (2) kháng thể phụ thuộc thuốc (drug-dependent antibodies) là loại kháng thể chỉ gắn với hồng cầu in vitro khi có thuốc, do kháng thể kháng lại cấu trúc phân tử của thuốc hoặc cấu trúc tạo bởi thuốc

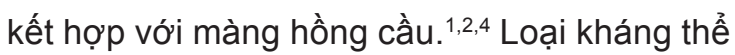
phụ thuộc thuốc thường gặp hơn trong DIIHA, tuy nhiên cả hai loại kháng thể này đều có thể được tạo ra đồng thời ở một cá thể trong cùng một phản ứng với thuốc. ${ }^{1}$

Liên quan đến loại kháng thể phụ thuộc thuốc, có hai cơ chế gắn thuốc với màng hồng cầu: (i) cơ chế hấp phụ thuốc (drug adsorption mechanism) do thuốc liên kết cộng hóa trị với màng hồng cầu như penicillin, cefotetan; (ii) 
cơ chế phức hợp miễn dịch (immune complex mechanism) với sự liên kết khá lỏng lẻo tạo ra kháng thể IgM, hoạt hóa bổ thể gây tan máu trong lòng mạch như ceftriaxone. ${ }^{4}$

Trong những năm gần đây, ceftriaxone được báo cáo là một trong những tác nhân quan trọng nhất gây ra DIIHA. ${ }^{2-4}$ Tan máu miễn dịch do ceftriaxone đặc trưng bởi nồng độ hemoglobin giảm mạnh đột ngột, tî lệ suy cơ quan cao và tỉ lệ tử vong ít nhất là $30 \%{ }^{3,6}$ Biến chứng này xảy ra ở trẻ em có bệnh cảnh lâm sàng nặng hơn và tiên lượng xấu hơn ở người lớn. 4,6

Do tính hiếm gặp và tiên lượng xấu, DIIHA ở trẻ em cần được các bác sĩ lâm sàng nhận biết để chẩn đoán chính xác và xử trí kịp thời. Chúng tôi báo cáo một trường hợp trẻ 19 tháng tuổi xuất hiện tan máu cấp tính gây suy tuần hoàn, suy thận sau điều trị kháng sinh ceftriaxone, được xử trí theo phác đồ sốc phản vệ tại bệnh viện địa phương. Chúng tôi chẩn đoán bệnh nhân bị tan máu tự miễn liên quan đến ceftriaxone và điều trị thành công bằng immunoglobulin đường tĩnh mạch.

\section{GIÓ'I THIẸU CA BẸNH}

Bệnh nhân nam, 19 tháng tuổi được đưa đến khám và nhập viện tại bệnh viện địa phương vì sốt cao và ho. Kết quả một số xét nghiệm của bệnh nhân lúc nhập viện: số lượng bạch cầu máu ngoại vi tăng (16 G/L), số lượng tiểu cầu (462 G/L) và nồng độ hemoglobin (121 $\mathrm{g} / \mathrm{L}$ ) bình thường; nồng độ protein $\mathrm{C}$ phản ứng (CRP) tăng nhẹ (8,7 mg/L); test cúm $A$ dương tính; X-quang ngực có hình ảnh viêm phổi. Bệnh nhân có tiền sử khỏe mạnh, chưa từng điều trị kháng sinh trước đây. Trẻ được chẩn đoán viêm phổi mắc phải tại cộng đồng và điều trị bằng kháng sinh Augmentin (amoxicillin - acid clavulanic) đường uống. Sau 5 ngày điều trị, do tình trạng viêm phổi tiến triển chậm, bệnh nhân được chuyển sang kháng sinh ceftriaxone tiêm tĩnh mạch liều 50 mg/kg/lần, 2 lần/ngày. Ngay sau tiêm ceftriaxone mũi thứ 11 , trẻ đột ngột xuất hiện tình trạng kích thích, mạch nhanh, nhợt và tiểu đỏ sẫm. Trẻ được xử trí theo phác đồ phản vệ, xét nghiệm máu cho thấy thiếu máu nặng (nồng độ hemoglobin $47 \mathrm{~g} / \mathrm{L}$ ), số lượng bạch cầu tăng rất cao $(72 \mathrm{G} / \mathrm{L})$, nồng độ $\mathrm{CRP}$ tăng nhẹ (13 mg/L) nên được chuyển đến Bệnh viện Nhi Trung ương để tìm nguyên nhân.

Tại Bệnh viện Nhi Trung ương, trẻ được chẩn đoán trên lâm sàng là tan máu cấp và chỉ định một số xét nghiệm với kết quả: thiếu máu nặng (nồng độ hemoglobin $64 \mathrm{~g} / \mathrm{L}$ ) hồng cầu bình sắc, tỷ lệ hồng cầu lưới tăng $(4,17 \%)$ trên huyết đồ; nồng độ lactacte dehydrogenase (LDH) máu tăng cao (2564,6 U/L), nồng độ bilirubin gián tiếp tăng nhẹ (nồng độ bilirubin toàn phần và bilirubin gián tiếp lần lượt là 45,9 umol/L và 38,5 umol/L) và huyết sắc tố niệu dương tính. Kết quả một số xét nghiệm để xác định nguyên nhân tan máu như hoạt độ men G6PD và điện di huyết sắc tố bình thường, test Coombs trực tiếp dương tính $3+$, test Coombs gián tiếp âm tính, nồng độ bổ thể C3, C4 huyết thanh đều giảm (tương ứng là $0,76 \mathrm{~g} / \mathrm{L}$ và 0,03 g/L), kháng thể kháng nhân âm tính. Một số xét nghiệm khác: số lượng tiểu cầu máu ngoại vi (296 G/L) và các chỉ số đông máu cơ bản (INR, $\mathrm{aPTT}$, fibrinogen) nằm trong giới hạn bình thường, số lượng bạch cầu tăng cao $(41,49$ $\mathrm{G} / \mathrm{L})$, ure máu tăng $(11,3$ umol/L), creatinine bình thường $(49,9$ umol/L), test cúm $A$ từ dịch mũi họng dương tính, xét nghiệm huyết thanh tìm nguyên nhân nhiễm trùng khác như CMV (cytomegalovirus), EBV (Epstain-Barr virus), HAV (hepatitis A virus), HEV (hepatitis E virus), HIV, Mycoplasma pneumoniae đều âm tính.

Chúng tôi chẩn đoán xác định bệnh nhân bị thiếu máu nặng do tan máu miễn dịch liên quan đến ceftriaxone nên dừng điều trị kháng sinh ceftriaxone, truyền khối hồng cầu cùng nhóm 
và chỉ định immunoglobulin tĩnh mạch liều $0,5 \mathrm{~g} / \mathrm{kg}$. Màu sắc nước tiểu nhạt dần sau khi dừng tiêm ceftriaxone (hình 1). Ngay sau điều trị, tình trạng bệnh nhân ổn định, nồng độ hemoglobin trở về bình thường và không còn tình trạng tan máu (biểu đồ 1), ure máu trở về bình thường sau 1 ngày, số lượng bạch cầu cũng giảm dần. Sau 4 ngày, chúng tôi làm lại xét nghiệm: nồng độ hemoglobin $114 \mathrm{~g} / \mathrm{L}$, số lượng bạch cầu 20,84 G/L, test Coombs trực tiếp dương tính 2+, nồng độ bổ thể bình thường. Bệnh nhân được xuất viện, tư vấn về việc không sử dụng kháng sinh nhóm ceftriaxone và các kháng sinh có khả năng phản ứng chéo với ceftriaxone.

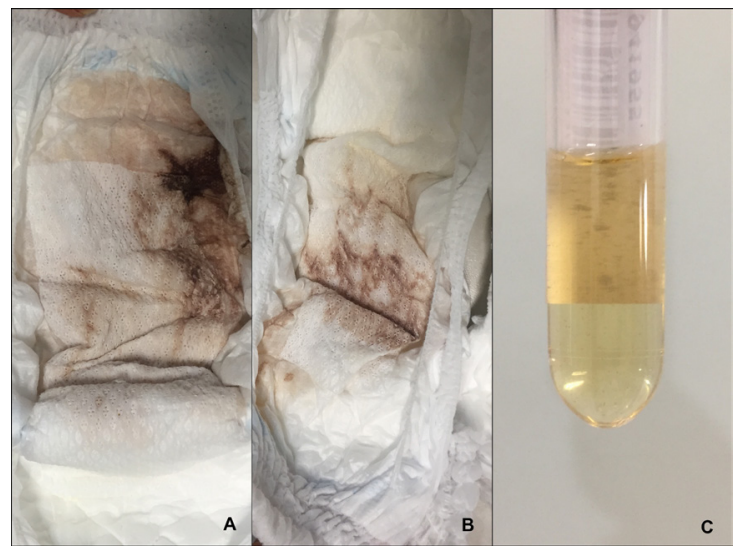

Hình 1. Thay đổi màu sắc nước tiểu sau tiêm ceftriaxone (A) sau 8 giò̀, (B) sau 12 giò̀, (C) sau 15 giò̀

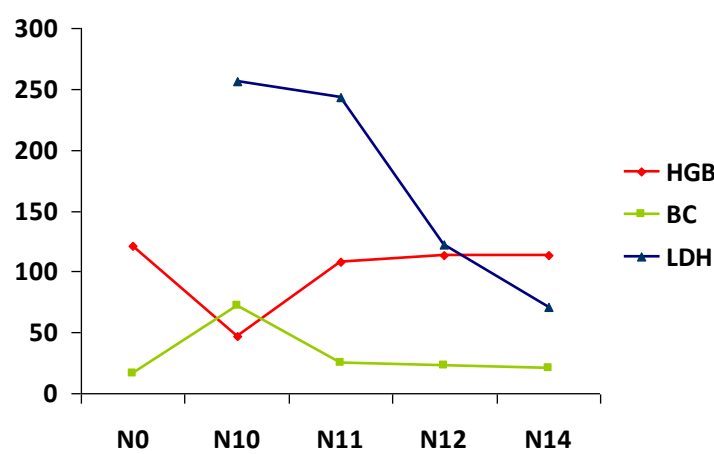

Biểu đồ 1. Thay đổi một số xét nghiệm máu của bệnh nhân

(HGB: nồng độ hemoglobin ( $\mathrm{g} / \mathrm{L})$, $B C$ : số lượng bạch cầu máu ngoại vi (G/L), LDH: nồng độ lactat dehydrogenase trong máu (U/dL), NO là ngày nhập viện tuyến địa phương).

\section{BÀN LUÂNN}

Ceftrixone được báo cáo là một trong các loại thuốc thường gặp nhất gây ra DIIHA trong thời gian gần đây. ${ }^{2,3}$ Một nghiên cứu hồi cứu trên 25 trường hợp DIIHA do ceftriaxone từ năm 1987 - 2010 cho thấy $64 \%$ số trường hợp được báo cáo xảy ra trong thập kỉ gần đây. ${ }^{6}$ Điều này có thể do khả năng nhận thức về DIIHA của các bác sĩ lâm sàng tăng lên trong thời gian gần đây. Ceftriaxone là loại cephalosporin phổ rộng, có thời gian bán thải tương đối dài nên được sử dụng rộng rãi để dự phòng và điều trị nhiễm khuẩn trong thực hành lâm sàng. Trên thực tế, DIIHA vẫn là một biến chứng hiếm gặp nên dễ bị bỏ sót chẩn đoán hoặc chẩn đoán nhầm với những tình trạng bệnh nặng khác.

Bệnh nhân chúng tôi báo cáo xuất hiện tình trạng kích thích, mạch nhanh ngay sau khi tiêm ceftriaxone nên được chẩn đoán và xử trí theo phác đồ sốc phản vệ tại bệnh viện địa phương. Tiếp cận và xử trí ban đầu này phù hợp tại tuyến y tế cơ sở. Tuy nhiên, trẻ nhợt nhanh và tiểu đỏ sẫm không phải là triệu chứng phản vệ. Mặt khác, trẻ không có biểu hiện mất máu hay chảy máu cấp nên tình trạng tan máu cấp có thể giải thích những triệu chứng lâm sàng ở bệnh nhân này. Kết quả các xét nghiệm khẳng định đây là tình trạng tan máu trong lòng mạch: thiếu máu hồng cầu bình sắc, tỷ lệ hồng cầu lưới máu ngoại vi tăng; nồng độ LDH máu tăng cao, nồng độ bilirubin gián tiếp tăng nhẹ và huyết sắc tố niệu dương tính. Test Coombs trực tiếp dương tính và nồng độ bổ thể trong máu giảm là bằng chứng của tan máu miễn dịch. 
Mặc dù không xác định được kháng thể liên quan đến ceftriaxone do hạn chế của phòng xét nghiệm, chúng tôi vẫn nghĩ đến nguyên nhân gây tan máu ở bệnh nhân này là do ceftriaxone bởi những đặc trưng về mặt lâm sàng: tan máu tự miễn trong lòng mạch cấp tính xuất hiện sau dùng thuốc, hồi phục sau khi ngừng thuốc (nồng độ hemoglobin $47 \mathrm{~g} / \mathrm{L}$ tăng lên $64 \mathrm{~g} / \mathrm{L}$ trước điều trị IVIG). Một số nghiên cứu hồi cứu tổng hợp các ca bệnh trên y văn đều cho thấy DIIHA do ceftriaxone ở trẻ em chiếm 68 - 70\% số ca. ${ }^{6,7}$ Hiện tượng tan máu do ceftriaxone xảy ra khá đột ngột với thời gian trung bình và thời gian trung vị từ khi tiếp xúc với thuốc đến khi xuất hiện triệu chứng tương ứng là 40 phút và 1 giờ (dao động từ 5 phút đến 5,6 giờ). ${ }^{7}$ Trong nghiên cứu 25 trường hợp DIIHA do ceftriaxone, nồng độ hemoglobin giảm rất thấp (19/25 trường hợp có $\mathrm{HGB} \leq 50$ g/L, trong đó 16 ca là trẻ em), 19/25 trường hợp có đặc điểm tan máu nội mạch (5/25 ca không có dữ liệu), 6/25 trường hợp suy thận (16/25 ca không có dữ liệu). ${ }^{6}$ Trong một nghiên cứu khác với 37 trường hợp cho thấy nồng độ hemoglobin giảm ở mức trung bình $55 \mathrm{~g} / \mathrm{L}$, $70 \%$ có test Coombs trực tiếp dương tính (6\% âm tính, 24\% không có dữ liệu), 70\% tăng nồng độ LDH máu, $51 \%$ tăng nồng độ bilirubin máu, $46 \%$ suy thận cấp. ${ }^{7}$

Tỉ lệ suy thận cấp ở bệnh nhân DIIHA cao không chỉ do giảm tưới máu/thiếu máu thận vì giảm nồng độ hemoglobin và sốc mà còn do độc tính trên thận của hemin và hemoglobin tự do. ${ }^{8}$ Ngoài độc tính trên thận, hemin và hemoglobin tự do còn có những tác động tiền viêm, có thể làm trầm trọng thêm bệnh cảnh lâm sàng của bệnh nhân DIIHA. ${ }^{9}$

Trong lần đầu tiên tiếp xúc với thuốc, hệ thống miễn dịch của bệnh nhân cần vài ngày để sản xuất ra kháng thể với thuốc. ${ }^{10}$ Đáp ứng miễn dịch thứ phát ở lần sử dụng thuốc sau khi đã có kháng thể thường gây ra những trường hợp DIIHA nặng. Trong nghiên cứu 37 trường hợp DIIHA do ceftriaxone: $65 \%$ trường hợp đã từng sử dụng ceftriaxone trước đó, $32 \%$ không có dữ liệu, chỉ $3 \%$ không có tiền sử điều trị ceftriaxone. $32 \%$ số trường hợp đã có đợt tan máu nhẹ, tự hồi phục do sử dụng ceftriaxone trước đó. ${ }^{7}$ Điều này chứng tỏ DIIHA còn bị bỏ sót chẩn đoán ở nhiều trường hợp và làm tăng lên tầm quan trọng khi khai thác tiền sử điều trị thuốc. Một điều đáng ngạc nhiên, các kháng thể phụ thuộc thuốc cũng được phát hiện ở những người khỏe mạnh với hiệu giá kháng thể thấp hơn nhiều so với ở bệnh nhân phát triển DIIHA. Hiện tượng này có thể do quá trình tiếp xúc với kháng sinh được sử dụng trong chăn nuôi nhưng mối liên quan trên lâm sàng vẫn chưa rõ. ${ }^{2}$ Tuy nhiên, hiện tượng này có thể giải thích những trường hợp DIIHA xảy ra sớm ở lần đầu sử dụng thuốc. Bệnh nhân của chúng tôi chưa được sử dụng kháng sinh ceftriaxone trước đây, trong đợt bệnh này sau khi tiêm ceftriaxone 5 ngày mới xảy ra hiện tượng tan máu và ngay sau khi dừng thuốc nồng độ hemoglobin tự cải thiện một phần trước khi điều trị bằng IVIG.

Hiện tượng tan máu ồ ạt, giảm nặng nồng độ hemoglobin cấp tính có thể gây ra các biến chứng nghiêm trọng như sốc (8\%), ngừng tuần hoàn $(16 \%)$, đông máu nội mạch rải rác (19\%), thiếu máu các cơ quan. ${ }^{7}$ Tỉ lệ tử vong của DIIHA do ceftriaxone rất cao, đặc biệt ở trẻ em: tỉ lệ tử vong 30 - 36\% tính chung cho tất cả các trường hợp, trong đó 64 - 67\% số trường hợp tử vong là trẻ em. . $^{6,7}$ Ceftriaxone gây ra bệnh cảnh lâm sàng nặng hơn và tỉ lệ tử vong cao hơn so với các thuốc khác gây ra DIIHA có thể do cơ chế tạo kháng thể phụ thuộc thuốc loại IgM hoạt hóa bổ thể dẫn đến tan máu trong lòng mạch nặng. 4,5,7

Trên lâm sàng, nếu nghi ngờ DIIHA, điều 
quan trọng nhất là ngừng thuốc ngay lập tức. Bệnh nhân DIIHA nên theo dõi tại đơn vị điều trị tích cực để được chăm sóc hỗ trợ tối ưu và điều trị hỗ trợ tuần hoàn nếu cần. Chỉ định truyền khối hồng cầu với lượng cần thiết. Trong nhiều trường hợp đã báo cáo, bệnh nhân được chỉ định điều trị bằng steroid nhưng không có bằng chứng về hiệu quả điều trị, việc "điều trị thành công" bằng steroid thực chất là do việc ngừng sử dụng thuốc gây tan máu. Do đó, không khuyến cáo liệu pháp steroid cho DIIHA với những trường hợp do kháng thể phụ thuộc thuốc. ${ }^{1,2}$ Trong trường hợp DIIHA do kháng thể không phụ thuộc thuốc - tự kháng thể, có thể điều trị thử bằng steroid ${ }^{1}$ nhưng quan trọng nhất vẫn là ngừng thuốc để dừng kích thích miễn dịch. Ngoài ra, DIIHA do kháng thể không phụ thuộc thuốc nếu có bằng chứng của tan máu nội mạch có thể điều trị bằng IVIG. ${ }^{11}$ Tuy nhiên, sự cải thiện về lâm sàng của bệnh nhân cũng chưa khẳng định là do tác dụng của IVIG hay do ngừng thuốc gây tan máu. Trong một số trường hợp, phương pháp trao đổi huyết tương hoặc lọc huyết tương được chỉ định trong DIIHA để loại bỏ các kháng thể do thuốc ra khỏi huyết thanh bệnh nhân, hữu ích trong DIIHA do cơ chế hấp phụ thuốc hoặc suy thận nặng. ${ }^{7}$

Sau khi chẩn đoán DIIHA cần hội chẩn bác sĩ chuyên khoa dị ứng về việc chống chỉ định dùng thuốc gây DIIHA suốt đời và xem xét rất cẩn thận các thuốc khác trong nhóm vì có thể xảy ra phản ứng chéo giữa kháng thể phụ thuộc thuốc với các thuốc tương tự. Trường hợp kháng thể phụ thuộc ceftriaxone có thể phản ứng chéo với cefotaxime, cefpodoxime, cefamandole, cefoperazone.. ${ }^{1,3}$ Với chẩn đoán tan máu miễn dịch liên quan đến ceftriaxone chúng tôi ngừng ngay ceftriaxone, do bệnh nhân có biểu hiện sốc và suy thận cấp chúng tôi quyết định điều trị IVIG và hội chẩn với chuyên khoa dị ứng để lựa chọn kháng sinh cho bệnh nhân.

\section{KÉT LUÂN}

Tan máu miễn dịch liên quan đến thuốc là một biến chứng tuy hiếm gặp nhưng có thể gây tử vong nếu không được chẩn đoán và xử trí phù hợp. Ceftriaxone là thuốc được báo cáo gây tan máu miễn dịch thường gặp nhất gần đây, với biểu hiện lâm sàng nặng và tỉ lệ tử vong cao, đặc biệt ở trẻ em. Các bác sĩ lâm sàng cần khai thác kĩ tiền sử dụng kháng sinh trước khi chỉ định, không lạm dụng thuốc và nhận biết được các biểu hiện bất thường trong và sau khi dùng thuốc để chẩn đoán kịp thời và dừng ngay các thuốc nghi ngờ.

\section{TÀI LIẸU THAM KHẢO}

1. Garratty G. Drug-induced immune hemolytic anemia. Hematol Am Soc Hematol Educ Program. Published online 2009:73-79. doi:10.1182/asheducation-2009.1.73.

2. Garratty G. Immune hemolytic anemia caused by drugs. Expert Opin Drug Saf. 2012;11(4):635-642. doi:10.1517/14740338.20 12.678832 .

3. Mayer B, Bartolmäs T, Yürek S, Salama A. Variability of Findings in Drug-Induced Immune Haemolytic Anaemia: Experience over 20 Years in a Single Centre. Transfus Med Hemotherapy. 2015;42(5):333-339. doi:10.1159/000440673.

4. Arndt PA. Drug-induced immune hemolytic anemia: the last 30 years of changes. Immunohematology. 2014;30(2):44-54.

5. Leicht HB, Weinig E, Mayer B, Viebahn J, Geier A, Rau M. Ceftriaxone-induced hemolytic anemia with severe renal failure: a case report and review of literature. BMC Pharmacol Toxicol. 2018;19(1):67. doi:10.1186/s40360018-0257-7.

6. Arndt PA, Leger RM, Garratty G. Serologic characteristics of ceftriaxone antibodies in 25 patients with drug-induced immune hemolytic anemia. Transfusion (Paris). 2012;52(3):602- 
612. doi:10.1111/j.1537-2995.2011.03321.x.

7.Neuman G, Boodhan S, Wurman I, et al. Ceftriaxone-induced immune hemolytic anemia. Ann Pharmacother. 2014;48(12):15941604. doi:10.1177/1060028014548310.

8. Deuel JW, Schaer CA, Boretti FS, et al. Hemoglobinuria-related acute kidney injury is driven by intrarenal oxidative reactions triggering a heme toxicity response. Cell Death Dis. 2016;7:e2064. doi:10.1038/cddis.2015.392.

9. Rifkind JM, Mohanty JG, Nagababu E. The pathophysiology of extracellular hemoglobin associated with enhanced oxidative reactions. Front Physiol. 2014;5:500. doi:10.3389/ fphys.2014.00500.

10. Salama A, Mayer B. Diagnostic pitfalls of drug-induced immune hemolytic anemia. Immunohematology. 2014;30(2):80-84.

11. Pierce A, Nester T. Pathology Consultation on Drug-Induced Hemolytic Anemia. Am J Clin Pathol. 2011;136(1):7-12. doi:10.1309/AJCPBVLJZH6W6RQM.

\section{Summary \\ CEFTRIAXONE-INDUCED HEMOLYTIC ANEMIA: A LIFE-THREATENING COMPLICATION}

Drug induced immune hemolytic anemia (DIIHA) is a rare complication and often underdiagnosed. However, DIIHA may lead to organ failure and can be fatal. Nowadays, ceftriaxone has been reported as one of the most common drugs causing DIIHA. We describe a 19-month-male diagnosed with pneumonia and treated with intravenous ceftriaxone twice daily at the local hospital. After 5 days of treatment, he suddenly developed tachycardia, became pale and had dark red urine so he was treated according to the protocol of anaphylaxis and transferred to the National Children's Hospital. He was diagnosed with ceftriaxone-induced immune hemolytic anemia. After discontinuation of ceftriaxone and receiving intravenous immunoglobulin, his symptoms improved quickly. Ceftriaxoneinduced immune hemolytic anemia is a rare but may cause immediately life-threatening condition. Treating physicians need to be aware for this complication to diagnose early and treat accordingly. An immediate withdrawal of the causative drug is essential to treat this condition.

Keywords: Hemolysis, drug-induced hemolytic anemia, ceftriaxone, children. 